\title{
Peningkatkan Hasil Belajar Matematika Materi Pembulatan Bilangan melalui Metode Giving Question and Getting Answer
}

\author{
Suprapto \\ SDN 2 Surodakan Kecamatan Trenggalek Kabupaten Trenggalek, Indonesia \\ supraptospd395@yahoo.co.id
}

\begin{abstract}
Abstrak: Berdasarkan hasil observasi menunjukkan bahwa perolehan nilai belajar matematika siswa kelas IV SDN 2 Surodakan masih di bawah standar KKM, yaitu kurang dari 70. Hal ini di sebabkan banyak siswa beranggapan bahwa pembelajaran matematika dipandang sulit dan berpengaruh pada nilai matematika siswa. Tujuan penelitian ini untuk meningkatkan hasil belajar matematika materi pembulatan bilangan melalui metode giving question and getting answer. Penelitian ini dilaksanakan di SDN 2 Surodakan, Trenggalek dengan metode PTK. Prosedur PTK memuat perencanaan, pelaksanaan tindakan, observasi, dan refleksi dengan dua siklus. Hasil penelitian menunjukkan ketuntasan klasikal siklus I 78,12\% dan siklus II 100\%.
\end{abstract}

\author{
Tersedia Online di \\ http://journal.unublitar.ac.id/pendidikan/i \\ ndex.php/Riset_Konseptual \\ Sejarah Artikel \\ Diterima pada: 26-01-2021 \\ Disetuji pada: 30-01-2021 \\ Dipublikasikan pada: 31-01-2021 \\ Kata Kunci: \\ matematika, pembulatan bilangan, metode giving \\ question and getting answer \\ DOI: \\ http://doi.org/10.28926/riset_konseptual.v5i1.317
}

\section{PENDAHULUAN}

Esensi dari suatu pembelajaran adalah hasil belajar yang ditunjukkan melalui perubahan tingkah laku siswa meliputi aspek kognitif, afektif, dan psikomotor. Selaras dengan pernyataan Sudjana (2010:3) bahwa semua upaya yang melibatkan proses berpikir disebut sebagai hasil belajar. Merujuk pada pemikiran Gagne (dalam Sudjana, 2010:3) bahwa hasil belajar tersebut memuat informasi verbal, keterampilan intelektual, kognitif, dan keterampilan motorik.

Sudjana (2010:78) menyebutkan factor keberhasilan belajar siswa, yaitu intern dan ekstern. Kedua faktor tersebut memiliki peranan penting sebagai pengaruh hasil belajar. Hal ini didukung oleh pernyataan Muhibbin Syah (2010:54) bahwa taraf keberhasilan siawa untuk memelajari suatu materi ajar dinyatakan melalui skor dari hasil tes setiap materi pelajaran. Dalam hal ini, hasil belajar disebut sebagai suatu tingkat penguasaan siswa terhadap materi ajar yang diikuti kemunculan rasa kepuasan terhadap hasil yang diperoleh dengan baik (Tjundjing, 2001:34). Selain itu, keberhasilan belajar sisea juga dipengaruhi oleh kemampuan siswa serta kualitas pembelajaran (kemampuan guru dalam mendesain pembelajaran atau profesionalitas seorang guru dalam mengemas suatu pembelajaran. Sehingga, kemampuan dasar guru yang perlu diprioritaskan adalah sikap (afektif), aspek kognitif (intelektual), dan bidang perilaku (psikomotorik).

Kegunaan hasil belajar juga diungkap oleh Bloom (dalam Anas, 2008:141) bahwa hasil belajar siswa dapat digunakan sebagai bentuk pengungkapan keberhasilan siswa saat belajar. Yang didapatkan dari sebuah hasil belajar adalah pemerolehan kecakapan dan pengetahuan hidup baru untuk diimplementasikan dalam beberapa indikator keberhasilan, berupa angka kelulusan, indeks prestasi belajar, predikat keberhasilan, dan nilai pada laporan belajar (rapor).

Tingkat keberhasilan siswa juga dipengaruhi oleh pembelajaran matematika. Pembelajaran matematika memiliki sifat yang hirarkis, yaitu antara penyampaian kegiatan pembelajaran dan materi ajar harus sesuai. Guru matematika dapat 
memberikan kegiatan pembelajaran yang mampu mengarahkan/membimbing siswa terkait bahan materi ajar matematika yang sedang dipelajari. Hal ini berguna sebagai pemaksimalkan sikap, pengetahuan, dan keterampilan tentang materi ajar matematika, terutama materi pembulatan bilangan.

Pembelajaran matematika seringkali termuat dalam kehidupan siswa, seperti melaksanakan pembulatan bilangan dalam satuan, puluhan, dan atau ratusan terdekat. Hal ini tentu berguna bagi siswa untuk memudahkan penentuan hasil operasi hitung. Namun, siswa kelas IV tidak mudah menerapan pembulatan bilangan ini di SDN 2 Surodakan Kecamatan Trenggalek Kabupaten Trenggalek.

Berdasarkan pengamatan, kesulitan tersebut dipengaruhi oleh tiga hal, yaitu penguasaan, ketertarikan, dan metode pembelajaran. Pertama, siswa tidak menguasai mata pelajaran matematika dari kelas sebelumnya. Hal ini tentu berdampak pada tingkatan selanjutnya, khususnya saat pembelajaran matematika kelas IV. Kedua, siswa kurang antusias dengan pembelajaran matematika. Ketertarikan atau antusias siswa untuk serius belajar matematika (pembulatan bilangan) dapat dilihat dari kegiatankegiatan belajar yang melibatkan siswa. Siswa cenderung biasa-biasa saja dan tidak seantusias saat belajar mata pelajaran lain. Ketiga, guru mengajarkan pembulatan bilangan dengan tutorial/ceramah melalui penjelasan di papan tulis. Hal ini tentu membuat siswa yang tidak memilikikeberanian bertanya, akan diam saja karena tidak ada kesempatan siswa untuk berdiskusi dan membahas bersama-sama soal-soal yang dihadapi.

Kesulitan-kesulitan siswa tersebut tentu dapat diatasi dengan pengubahan cara belajar pembulatan bilangan di kelas. Guru perlu berinovasi dengan berbagai cara agar dapa mengurangi kesulitan siswa, seperti menggunaka metode pembelajaran yang sesuai. Guru menggunakan metode pembelajaran sebagai cara pengembangan desain pembelajaran pada materi-materi tertentu. Sehingga, guru menyesuaikan materi dengan metode pembelajaran yang efektif dan tepat agar tercipta kondisi pembelajaran yang menyenangkan dan selaras dengan materi pembeljaran

Metode pembelajaran Giving Questions and Getting Answer sebagai metode yang mengimplementasikan metode pembelajaran kontrukstivistik berpeluang untuk membantu keberhasilan siswa untuk menguasai pembulatan bilangan. Metode pembelajaran Giving Questions and Getting Answer diimplementasikan untuk melatih siswa memiliki pengetahuan dan keterampilan bertanya dan menjawab pertanyaan. Metode ini dimodifikasi dengan kolaborasi menggunakan potingan kertas sebagai media Tanya-jawab (http://sejarahklasik.blogspot.com, tanggal 1 September 2019 pukul 12.15).

Kegiatan Tanya-jawab melalui metode Giving Questions and Getting Answer merupakan kegiatan yang pada hakikatnya menerapkan hubungan berinteraksi antara guru dan siswa. Utami (2020:98) menyatakan bahwa that interaction means is communication. Aktivitas yang biasa dilaksanakan oleh guru dan siswa dalam kegiatan belajar mengajar dapat dilakukan melalui komunikasi yang baik tentunya akan mampu membantu siswa untuk mengonstruksikan pengetahuan yang diberikan oleh guru. Kemudahan metode ini dapat dilaksanakan secara bergantian dengan metode lainnya, seperti ceramah. Hal ini untuk menghindari siswa dalam keadaan black mind. Metode pendamping yang digunakan, seperti metode ceramah dapat membantu siswa memeroleh pengetahuan dasar (prior knowledge). Sehingga, perpaduan medode giving question and getting answer dengan metode ceramah dapat mengaktifkan siswa saat belajar matematika dan mampu merekonstruksi pengetahuan siswa.

Matematika sifatnya hierarkis tentu penyampaian pembelajaran harus selaras dengan materi ajar. Keberhasilan suatu pembelajaran dapat didukung dengan penggunaan metode pembelajaran yang tepat.

\section{METODE}

Metode Penelitian Tindakan Kelas (PTK) digunakan dalam pelaksanaan penelitian ini. Subjek penelitian yaitu siswa kelas IV SDN 2 Surodakan Kecamatan 
Trenggalek Kabupaten Trenggalek tahun ajaran 2018-2019 berjumlah 32 siswa. Tindakan pembelajaran dilakukan dua siklus (masing-masing siklus terdiri atas dua pertemuan). Siklus I dilaksanakan pada 6 dan 13 Agustus 2018 memuat $4 \times 35$ menit (2 pertemuan) dan siklus II dilaksanakan pada 20 dan 27 Agustus 2018 memuat $4 \times 35$ menit (2 pertemuan). Kedua siklus dilaksanakan selama 28 hari.

PTK ini dilakukan melalui prosedur, berupa merencanakan, melaksanakan, pengamatan, dan refleksi. Data dikumpulkan dengan teknik observasi dan teknik tes. Teknik observasi merupakan teknk dengan memusatkan perhatian pada suatu objek melibatkan seluruh indra manusia (Arikunto, 2003:146). Penelitian ini menggunakan observasi partisipan artinya observer melibatkan diri dalam kegiatan belajar siswa. Adapun teknis tes dilaksanakan secara klasikal pada akhir kegiatan pembelajaran. Dalam hal ini tes digunakan untuk mengetahui peningkatan prestasi belajar Matematika materi pembulatan bilangan berupa tingkat penguasaan materi ajar. Tes berbentuk isian yang terdiri dari 10 soal.

Data dianalisis secara deskriptif kualitatif dan kuantitatif. Penentuan nilai hasil tes pada siklus I dan siklus II diolah dengan rumus, $\mathrm{N}=\frac{\sum B}{\sum S I} \mathrm{x} 100$ dengan keterangan $\mathrm{N}=$ nilai, $\Sigma \mathrm{B}=$ skor peserta didi, dan $\Sigma \mathrm{SI}=$ skor maksimal. Selanjutnya, mencari nilai ratarata pada setiap siklus diolah dengan rumus sebagai berikut. $\mathrm{RT}=\frac{\sum j n}{\sum j s}$ dengan keterangan $\mathrm{RT}=$ rata-rata, $\sum \mathrm{j}$ =jumlah nilai, dan $\sum \mathrm{j}$ s=jumlah siswa. Siswa dinyatatakan telah berhasil apabila memeroleh nilai sama atau lebih besar dari KKM 70. Adapun secara klasikal dinyatakan tuntas apabila siswa memeroleh nilai sama atau lebih dari $85 \%$. Rumus menghitung ketuntasan klasikal sebagai berikut. $\mathrm{TK}=\frac{J T}{J S} \times 100 \%$ dengan keterangan TK=ketuntasan klasikal, JT=jumlah tuntas, dan JS=jumlah siswa.

\section{Pra Siklus atau Kondisi Awal}

\section{HASIL dan PEMBAHASAN}

Data hasil kegiatan pembelajaran sebelumnya dipergunakan dasar mengadakan tindakan. Proses pembelajaran Kelas IV SDN 2 Surodakan Kecamatan Trenggalek Kabupaten Trenggalek masih menggunakan metode konvensional, berupa metode ceramah. Hal ini berpengaruh pada kegiatan pembelajaran yang monoton dan tingkat partisipasi siswa yang menurun. Kondisi ini tentu berdampak pada keberhasilan siswa memelajari materi pembulatan bilangan pada mata pelajaran matematika. Dengan demikian, siswa tidak aktif mengikuti proses pembelajaran, nilai hasil ulangan harian $50 \%$ dari 14 siswa. Ketuntasan klasikal mencapai 50\% dari yang ditetapkan $85 \%$.

\section{Kegiatan dan Hasil Pelaksanaan Siklus I Perencanaan}

Siklus I merencanakan kegiatan, berupa: menyusun perangkat pembelajaran (silabus dan RPP), merancang dan membuat kartu pertanyaan dan kartu menjawab, membuat soal ulangan, dan membuat lembar catatan tindakan.

\section{Pelaksanaan Tindakan}

Siklus I dilaksanakan pada Senin, 6 Agustus 2018 dan pertemuan II dilakukan pada Senin, 13 Agustus 2020. Pembelajaran siklus I dilakukan dua pertemuan dengan waktu 2x35 menit. Pelaksanaan tindakan ini sebagai berikut.

Tabel 1 Pelaksanaan Tindakan Siklus I

\begin{tabular}{|c|c|c|}
\hline \multicolumn{3}{|c|}{ Pertemuan I (6 Agustus 2018) } \\
\hline $\begin{array}{l}\text { Kegiatan Awal } \\
\text { (10 menit) }\end{array}$ & $\begin{array}{l}\text { Kegiatan inti } \\
\text { (50 menit) }\end{array}$ & $\begin{array}{l}\text { Kegiatan akhir } \\
\text { (10 menit) }\end{array}$ \\
\hline $\begin{array}{l}\text { 1) Guru mendata kehadiran } \\
\text { siswa. Semua siswa } \\
\text { hadir. } \\
\text { 2) Guru memaparkan secara }\end{array}$ & $\begin{array}{l}\text { 1) Guru memberikan } 2 \text { kartu } \\
\text { kepada setiap siswa yang } \\
\text { memuat kartu pertanyaan } \\
\text { dan kartu jawaban. }\end{array}$ & $\begin{array}{l}\text { Guru dan siswa } \\
\text { merefleksikan kegiatan } \\
\text { pembelajaran melalui tanya- } \\
\text { jawab. Guru membimbina }\end{array}$ \\
\hline $\begin{array}{l}\text { singkat kegiatan } \\
\text { pembelajaran. }\end{array}$ & 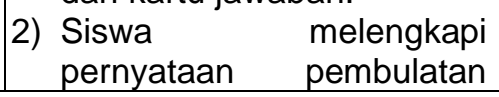 & $\begin{array}{l}\text { siswa menyimpulkan hasil } \\
\text { pembelajaran. }\end{array}$ \\
\hline
\end{tabular}


3) Guru menyampaiakan KD 3.3 Memahami aturan pembulatan dalam membaca hasil pengukuran dengan alat ukur.

4) Tujuan pembelajaran: (1) Siswa mampu membulatkan bilangan ke satuan terdekat, (2) Siswa dapat membulatkan bilangan ke Puluhan Terdekat, (3) Siswa dapat mengubah soal cerita pembulatan bilangan satuan dan puluhan ke dalam kalimat matematika. Kemudian guru memberikan apersepsi tentang meteri perajaran. bilangan berikut ini. (1)

Kartu 1 : saya masih belum paham tentang pembulatan bilang satuan. (2) Kartu 2 : saya dapat menjelaskan tentang pembulatan bilang satuan.

3) Siswa terbagi dalam 4 kelompok beranggotakan 8 siswa. Masing-masing anggota kelompok untuk bertanya menggunakan (kartu 1) tentang pembulatan bilangan satuan dan atau menjawab pertanyaan dengan (kartu 2) tentang pembulatan bilangan satuan atau puluhan misal penjumlahan bilanggan disampingg bila dibulatkan menjadi $22+10=\ldots$.

4) Siswa membaca pertanyaan yang telah disusun untuk dijawab oleh teman dan atau guru.

\section{Pertemuan II (13 Agustus 2018)}

1) Guru mendata kehadiran siswa. Semua siswa hadir.

2) Guru menyampaikan kegiatan belajar.

3) Guru mengawali dengan apersepsi.
1) Setiap kelompok menyampaikan materi yang ada pada kartu 2 tentang pembulatan bilangan satuan atau puluhan.

2) Guru minta kepada salah satu anggota kelompok untuk menyampaikannya penjelasan dari kartu 2 tentang pembulatan bilangan satuan atau puluhan kepada siswa lain.

3) Siswa mengerjakan sosl ulangan

\section{Observasi}

Hasil pengamatan tersaji sebagai berikut. (a) Waktu guru membagi kartu suasana kelas ramai, (b) guru meminta setiap siswa untuk menyampaikan pembulatan bilangan, tetapi siswa belum memahami, (c) membuat pertanyaan dengan (kartu 1) pembulatan satuan atau puluhan, dan topik yang siswa paparkan (melalui kartu ke-2) tentang pembulatan satuan atau puluhan, hasilnya suasana kelas gaduh, (d) guru minta kepada salah satu anggota kelompok untuk menyampaikannya penjelasan dari kartu 2 tentang pembulatan satuan atau puluhan kepada siswa lain. Namun, tidak semua siswa bersedia.

\section{Refleksi}

Adapun hasil ulangan siswa dapat disajikan sebagai berikut.

Tabel 2 Hasil Ulangan Siswa Siklus I

\begin{tabular}{|c|c|c|c|c|c|}
\hline NO & NILAI & FREKUENSI & N X F & PROSENTASE & PAPARAN \\
\hline 1 & 60 & 7 & 420 & $21,87 \%$ & Belum Tuntas \\
\hline 2 & 70 & 10 & 700 & $31,25 \%$ & Tuntas \\
\hline
\end{tabular}




\begin{tabular}{|c|c|c|c|c|c|}
\hline 3 & 80 & 7 & 560 & $21,87 \%$ & Tuntas \\
\hline 4 & 90 & 5 & 450 & $15,63 \%$ & Tuntas \\
\hline 5 & 100 & 3 & 300 & $9,38 \%$ & \\
\hline JUMLAH & 32 & 2.430 & $100 \%$ & \\
\hline \multicolumn{2}{l}{ RATA-RATA } & 75,93 & & \\
\hline \multicolumn{2}{l}{ KETUNTASAN KLASIKAL } & $78,12 \%$ & & \\
\hline
\end{tabular}

Berdasarkan tabel 2 menunjukkan, (a) nilai 60 diperoleh 7 orang siswa atau $21,87 \%$ dari 32 siswa, (b) nilai 70 diperoleh 10 orang siswa atau $31,25 \%$ dari 32 siswa, (c) nilai 80 diperoleh 7 orang siswa atau $21,87 \%$ dari 32 siswa, (d) nilai 90 diperoleh 5 orang siswa atau $15,63 \%$ dari 32 siswa, (e) nilai 100 diperoleh 3 orang siswa atau $9,38 \%$ dari 32 siswa, (f) rata-rata ulangan siswa siklus I adalah 75,93\%, (g) siswa belum tuntas siklus I adalah 21,87\%, (h) siswa tuntas siklus I berjumlah 78,12\%, (i) ketuntasan secara klasikal siklus I 78,12\%.

Berdasarkan hasil ulangan siswa dan observasi siswa mengikuti pembelajaran peneliti mengadakan refleksi sebagai berikut. (a) Waktu guru membagi kartu perhatian guru terhadap siswa masih kurang akibatnya siswa ramai, (b) beberapa siswa untuk melengkapi pernyataan pembulatan satuan atau puluhan ada siswa belum paham, (c) suasana kelas gaduh membuat pertanyaan yang ada (kartu 1) tentang pembulatan satuan atau puluhan, dan (d) menyampaikannya penjelasan dari kartu 2 tentang pembulatan satuan atau puluhan kepada siswa lain tidak semua siswa mau.

\section{Kegiatan dan Hasil Pelaksanaan Siklus II \\ Perencanaan}

Dalam perencanaan ini penulis melaksanakan meliputi: membuat silabus, membuat RPP, membuat 2 kartu untuk bertanya dan menjawab, membuat soal ulangan, dan membuat lembar catatan tindakan.

\section{Pelaksanaan Tindakan}

Tindakan siklus II dilakukan pada Senin 20 dan 27 Januari 2018 pembelajaran siklus II dilakukan 2 pertemuan. Satu kali pertemuan 2x35 menit. Pelaksanaan tindakan sebagai berikut.

Tabel 3 Pelaksanaan Tindakan Siklus II

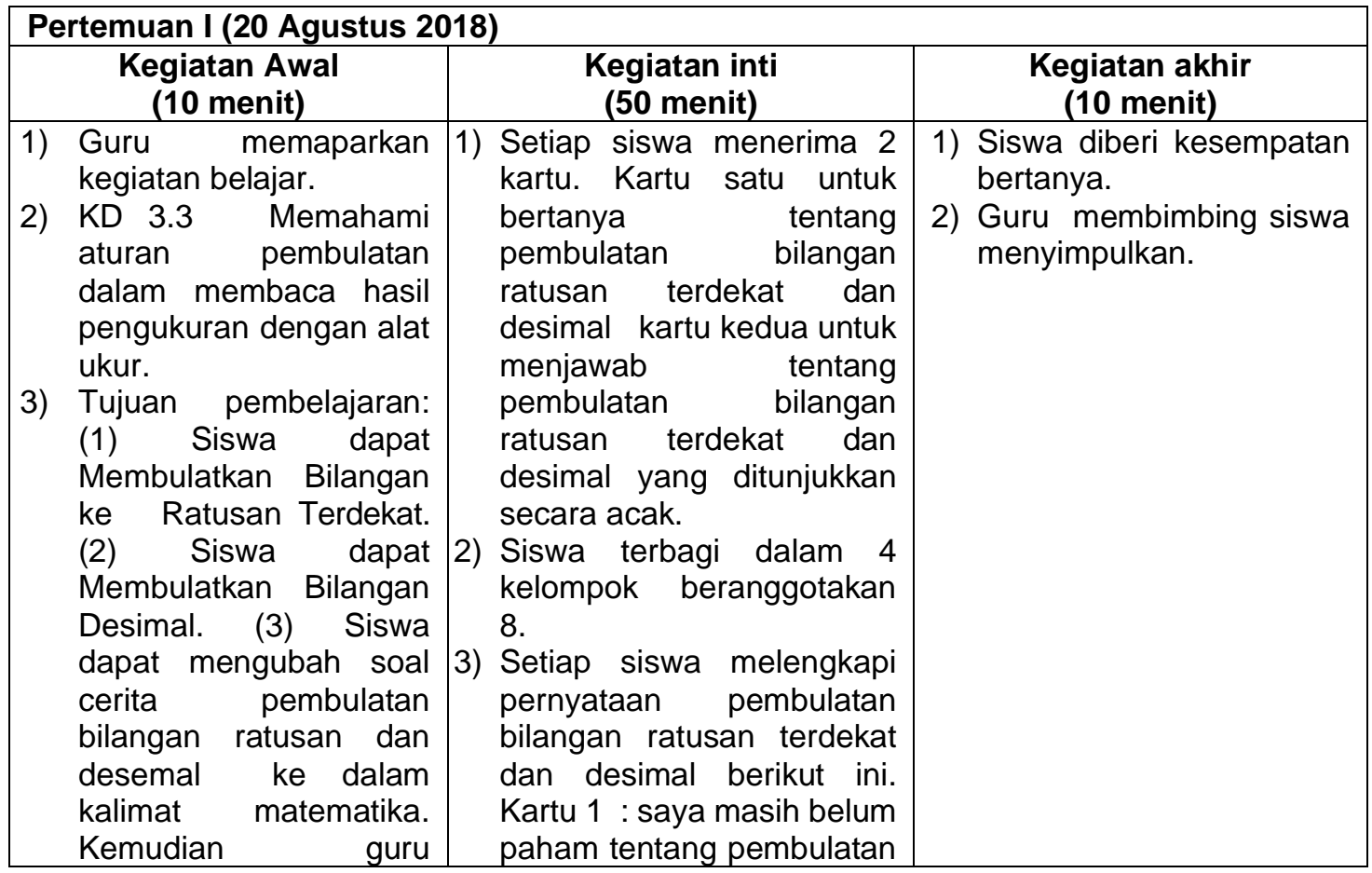




\begin{tabular}{|c|c|c|c|c|}
\hline & $\begin{array}{lr}\text { memberikan } & \text { apersepsi } \\
\text { tentang } & \text { meteri } \\
\text { pelajaran. } & \end{array}$ & & 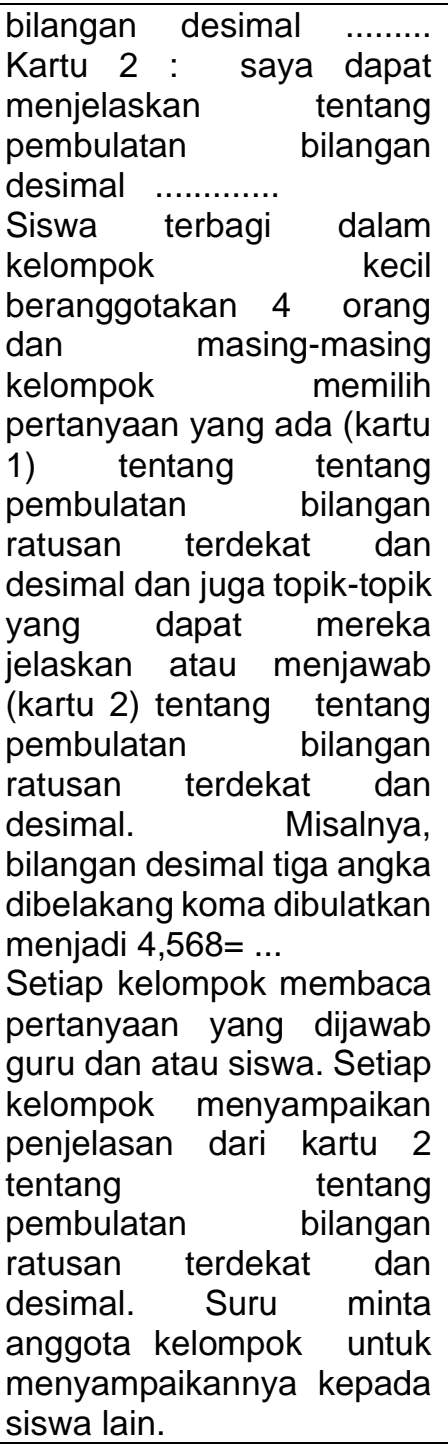 & \\
\hline \multicolumn{5}{|c|}{ Pertemuan II (27 Agustus 2019) } \\
\hline 3) & $\begin{array}{l}\text { Guru mengecek } \\
\text { kehadiran siswa, siswa } \\
\text { hadir semua. } \\
\text { Guru menyampaikan } \\
\text { kegiatan belajar. } \\
\text { Gurum menyajikan } \\
\text { apersepsi. }\end{array}$ & & 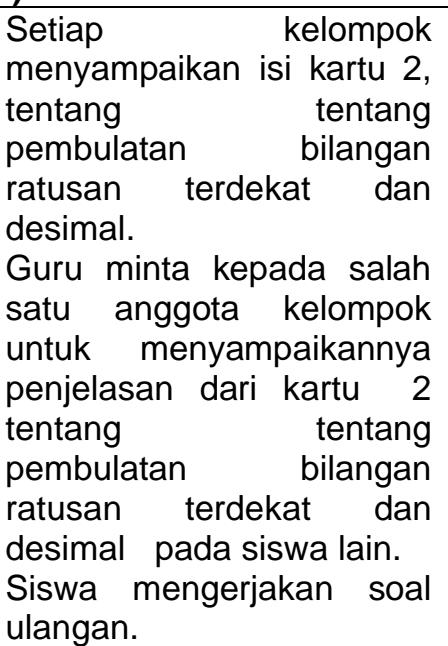 & $\begin{array}{l}\text { 1) Siswa diberi kesempatan } \\
\text { bertanya. } \\
\text { 2) Guru mendampingi siswa } \\
\text { menyimpulkan bahan } \\
\text { ajar. }\end{array}$ \\
\hline
\end{tabular}

\section{Observasi}

Hasil pengamatan saat kegiatan pembelajaran sebagai berikut. (a) Waktu guru membagi kartu suasana kelas kondosif. (b) Setiap siswa diminta untuk melengkapi pernyataan tentang penerapan dalam kehidupan sehari-hari pembulatan ratusan atau desimal sudah paham. (c) Memilih pertanyaan yang ada (kartu 1) tentang penerapan dalam kehidupan sehari-hari pembulatan ratusan atau desimal suasana kelas tenang. 
(d) Guru minta kepada salah satu anggota kelompok untuk menyampaikannya penjelasan dari kartu 2 tentang penerapan dalam kehidupan sehari-hari pembulatan ratusan atau desimal kepada siswa lain semua siswa mau.

\section{Refleksi}

Adapun hasil ulangan siswa dapat disajikan sebagai berikut.

Tabel 3 : Hasil Ulangan Siswa Siklus II

\begin{tabular}{|c|c|c|c|c|c|}
\hline NO & NILAI & FREKUENSI & N X F & PROSENTASE & PAPARAN \\
\hline 1 & 70 & 11 & 770 & $34,37 \%$ & Tuntas \\
\hline 2 & 80 & 9 & 720 & $28,16 \%$ & Tuntas \\
\hline 3 & 90 & 7 & 630 & $21,85 \%$ & Tuntas \\
\hline 4 & 100 & 5 & 500 & $15,62 \%$ & Tuntas \\
\hline \multicolumn{2}{l}{ JUMLAH } & 32 & 2.620 & $100 \%$ & \\
\hline \multicolumn{2}{l}{ RATA-RATA } \\
\multicolumn{2}{l}{ KETUNTASAN KLASIKAL } & 81,87 & & \\
\hline
\end{tabular}

Tabel tersebut menyajikan, (a) nilai 70 diperoleh 11 orang siswa atau $34,37 \%$ dari 32 siswa. (b) Nilai 80 diperoleh 9 orang siswa atau $28,16 \%$ dari 32 siswa. (c) Nilai 90 diperoleh 7 orang siswa atau $21,85 \%$ dari 32 siswa. (d) Nilai 100 diperoleh 5 orang siswa atau 15,62\% dari 32 siswa. (e) Rata-rata ulangan siswa siklus II adalah 81,87\%. (f) Siswa tuntas siklus II adalah 100\%. (g) Ketuntasan secara klasikal siklus II 100\%.

Berdasarkan hasil ulangan siswa dan observasi siswa mengikuti pembelajaran peneliti mengadakan refleksi sebagai berikut. (a) Waktu guru membagi kartu perhatian guru terhadap siswa tidak ramai. (b) Semua siswa untuk melengkapi pernyataantentang penerapan dalam kehidupan sehari-hari pembulatan bilangan ratusan terdekat dan desimal sudah paham. (c) Suasana kelas tenangmemilih pertanyaan yang ada (kartu 1) tentang penerapan dalam kehidupan sehari-hari pembulatan bilangan ratusan terdekat. (d) Menyampaikannya penjelasan dari kartu 2 tentang penerapan dalam kehidupan sehari-hari pembulatan bilangan ratusan terdekat dan desimal kepada siswa lain semua siswa mau.

\section{Pembahasan Hasil Tindakan}

Hasil penelitian siklus I dan II disajikan melalui diagram berikut.

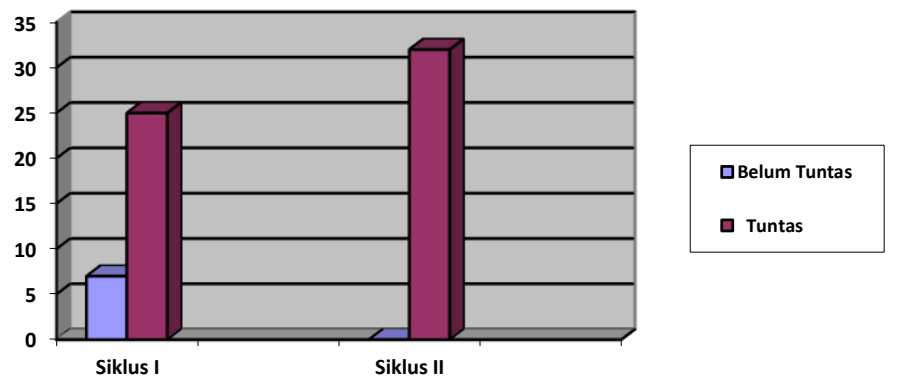

Diagram 1. Siswa Belum Tuntas dan Tuntas pada Siklus I dan II

Diagram 1 menunjukkan ketuntasan siswa pada siklus I berjumlah 7 siswa atau $21,87 \%$, kategori tuntas diperoleh 25 orang siswa atau $78,12 \%$ dari 32 orang siswa. Siklus II semua siswa tuntas atau $100 \%$ dari 14 orang siswa. Penguasaan materi pada siklus II meningkat. Terbukti pada ketuntasan siswa dengan perolehan nilai $\geq K K M$ yaitu 70 pada siklus I menuju siklus II mengalami kenaikan yang signifikan yaitu $21,87 \%$. 


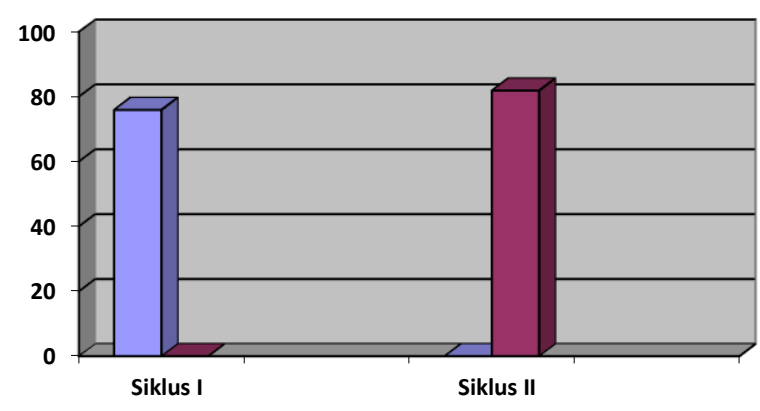

Diagram 2. Daftar Nilai Rata-Rata Siklus I dan II

Kenaikan nilai rata-rata siswa pada siklus 1 dan 2 ditunjukkan melalui perolehan persentase 65,93 dan siklus II rata-rata 81,87 . Nilai rata- rata siswa mengalami peningkatan 5,94 .

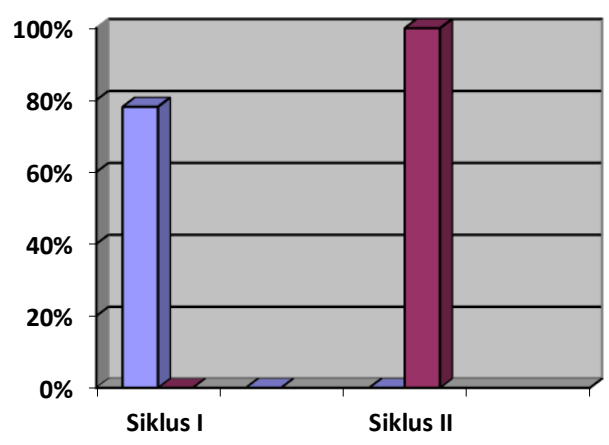

$\square$ Prosentase Ketuntasan Siklus

$\square$ Prosentase Ketuntasan Siklus II

Diagram 3. Persentase Ketuntasan Belajar Siswa Siklus I dan II

Secara klasikal, hasil belajar matematika materi pembulatan bilangan meningkat. Hal ini dapat dilihat pada diagram 3 siklus I 78,12\% dan siklus II $100 \%$. Ketuntasan klasikal siswa pada siklus II di atas $85 \%$ atau $21,88 \%$. Hasil belajar siswa ditunjukkan melalui tabel 4 berikut ini.

Tabel 4. Perbandingan Hasil Belajar Siswa Siklus I dan II

\begin{tabular}{|c|l|c|c|}
\hline No & Hasil Belajar Siswa & Siklus I & Siklus II \\
\hline 1 & Belum Tuntas & $21,87 \%$ & $0 \%$ \\
\hline 2 & Tuntas & $78,12 \%$ & $100 \%$ \\
\hline 3 & Ketuntasan Klasikal & $78,12 \%$ & $100 \%$ \\
\hline
\end{tabular}

Berdasarkan tabel 4 dapat dijelaskan sebagai berikut.

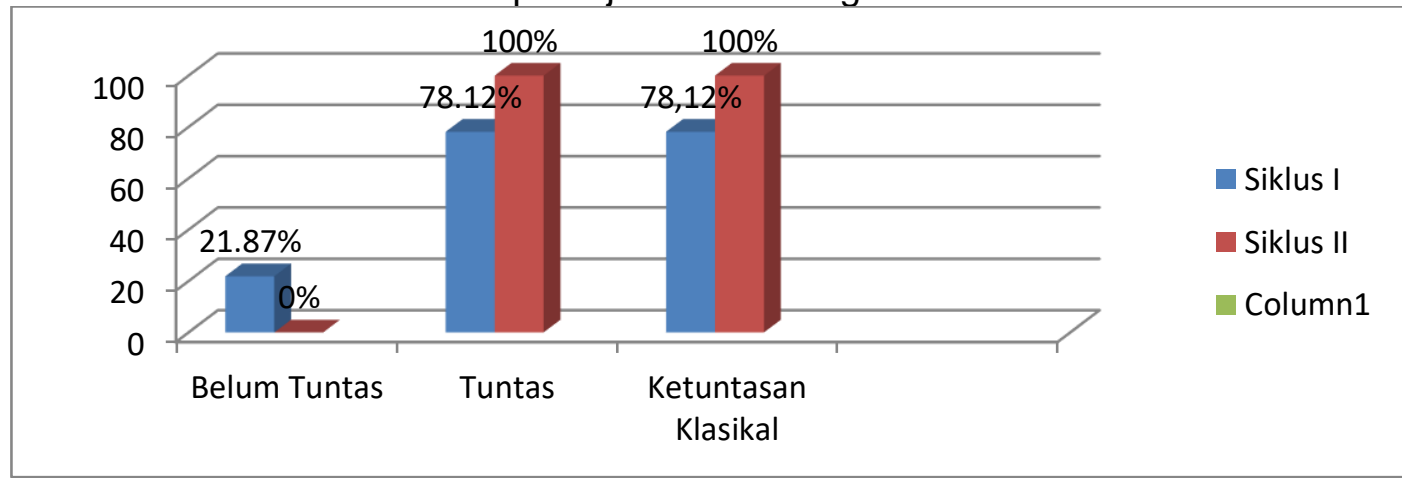

Diagram 4. Perbandingan Hasil Belajar Siswa Siklus I dan II 
Nilai ulangan siswa rata-rata pada siklus I dan II mengalami kenaikan yaitu : siklus I rata-rata I 68,57 dan siklus II rata-rata 81,67.

\section{KESIMPULAN}

Hasil ulangan dan hasil pengamatan menunjukkan hasil belajar meningkat. Hal ini ditunjukkan pada siklus 1 yaitu siswa yang belum tuntas berjumlah 7 siswa atau $21,87 \%$, tuntas sejumlah 25 siswa atau $78,12 \%$ dari 32 siswa. Siklus II semua siswa tuntas atau $100 \%$ dari 32 siswa. Rata-rata nilai ulangan siswa siklus I dan II mengalami kenaikan yaitu siklus I rata-rata 75,93 dan siklus II rata-rata 81,87 . Ketuntasan klasikal siklus I 78,12\% dan siklus II 100\%. Secara klasikal telah tuntas karena siswa yang tuntas di siklus II di atas $85 \%$.

\section{DAFTAR RUJUKAN}

Azwar, Anas. 2008. Tes prestasi: Fungsi dan Pengembangan Pengukuran Prestasi Belajar. Yogyakarta: Pustaka Pelajar.

Dewi Nuharini, Sulis Priyanto. 2016. Mari belajar matematika: Pendidikan Matematika. Surakarta: CV. Usaha Makmur.

http://sejarahklasik.blogspot.com, tanggal 1 September 2019 pukul 13.14

http://sucikorafi.multiply.com/ journal/item/ 4 /skripsi nurdahlia diakses 1 September 2019 Pukul 13. 14.

Hudoyo H. Kemmis, S. dan Mc. Taggart. R. 1990. Strategi Belajar Mengajar Matematika. Malang: IKIP Malang.

Kementerian Pendidikan dan Kebudayaan. 2016. Buku Tema 5 Aku dan Rumahku-Edisi Revisi. Jakarta : Kementerian Pendidikan dan Kebudayaan.

Muhibbin Syah. 2010. Psikologi Pendidikan dengan Pendekatan Baru. Bandung: PT Remaja Rosdakarya.

Nana Sudjana. 2010. Penilaian Hasil Proses Belajar Mengajar. Bandung: PT Remaja Rosda Karya.

Slameto. 2003. Belajar dan Faktor- Faktor yang Mempengaruhi. Jakarta: Rineka Cipta. Suharsimi Arikunto. 2003. Dasar-Dasar Evaluasi Pendidikan. Jakarta: Bumi Aksara.

Utami, S dan Lailiyatus Sa'diyah. 2021. The Development of Negotiation Text Oriented to Higher Order Think-ing Skills (HOTS) for Teaching Material with the Context of Life Skills in the Business and Industrial World. Dalam Journal of Development Research, Volume 4, Nomor 2, November 2020, hlm. 97-105. 